\title{
Property as a Source of Inspiring Dance Creation for Elementary School Students
}

\author{
Desfiarni $^{1}$ and Fuji Astuti ${ }^{1, *}$ \\ ${ }^{I}$ Dance, drama and music Education, Universitas Negeri Padang, Padang, Indonesia \\ *Corresponding author. Email: astuti@fbs.unp.ac.id; desfiarni@fbs.unp.ac.id
}

\begin{abstract}
It is difficult for a class teacher to teach dancing course at school, because they find it very difficult to find the movements that will be knitted. These prolonged complaints will not end if there is no effort to always try and do something that is very possible to be done by class teachers. Dancing properties can be used as a source of inspiration in finding motion through the exploration process. The properties are those that are resulted by the children's handicrafts that are taught in handicraft materials, for example making fans from origami paper, cigarette ashtrays from shells, kites and so on. The teacher guides students to make fan hand crafts with colorful paper, giving rise to the pattern and character of the color. Starting from the color character of the property, the teacher guides students to explore motion, so that they find motion motifs that are characterized by the color that is used as a medium for exploring motion. The forms of motion motifs that appear are the result of exploration supported by the knowledge, observation, appreciation, and imagination of children which are expressed through motion that comes from the handicrafts/property of the child himself. Furthermore, the teacher and the children collaborate to try to arrange these motion motifs in a series of dances that can be done without coercion, but are fun and carried out with a play approach. On the other hand, shell as a result of the handicraft is able to be used as an inspiration for exploring motion, and it can also function as a property in dance, so that a series of fan dances and shell dances is formed.
\end{abstract}

Keywords: handcrafts, properties, motion exploration, dance

\section{INTRODUCTION}

Cultural arts education that is taught in the elementary school context includes arts of music, dance, theater, fine arts, and handicrafts. All of them are integrated and connected in one unit called thematic. This is in accordance with the purpose of cultural arts education which is multilingual, multi-dimensional and multicultural. This means that the content contained in multilingual means the development of the ability to express oneself creatively in various ways and media such as visual language, sound, motion, roles and various combinations. Multidimensional means the development of various competencies including conception (knowledge, understanding, analysis, evaluation), appreciation, and creation by harmoniously combining elements of aesthetics, logic, kinesthetics, and ethics [1]. The multicultural nature implies that art education develops awareness and ability to appreciate the various cultures of the Archipelago and Abroad. This last component cannot be achieved due to limited resources/teachers [2]. The three components form a democratic attitude that allows a person to live in a civilized and tolerant manner in a pluralistic society and culture. It can be imagined that if students do not get cultural arts education, the balance of the right brain and left brain cannot be felt by students. This has a negative impact on the development of the child's competence. Students learn without variations, the material is only focused on processing the left brain, so that the right brain is not functioning. While learning arts and culture at the elementary level aims to foster a sense of sensitivity and creativity of students which is expressed through art media [3, 4]. This means that a child at the kindergarten level is not required to be a reliable dancer, as stated by Salmurgianto, that children in vocational schools are not required to be professional artists but rather to provide aesthetic experiences to children [5].

SD N 03 and SD N 18 are located in Jorong Harapan Tinggam which have just been separated from the isolated area, but they are still in the same village in Jorong Tobang sub-district. Talamau, Kab. Pasaman Barat.. In Jorong Harapan Tinggam, there are only 2 elementary schools and the people work as farmers. Jorong Harapan Tinggam is quite far from the subdistrict center, but it is quite easy to reach with adequate means of transportation, even though you have to pass through hilly areas. This school has never had a touch of anchovy dance practice, due to the limitations of teachers who do not have a background in dance expertise. If this is allowed to continue, it will adversely 
affect the balance of the right brain and left brain which should have been obtained by students starting at an early age.

We realize that each student has a potential to dance and it needs to explore the potential. They do not get maximum direction and guidance by their teachers. One of the reasons is that it is closely related to the competence of teachers who should act professionally, as the tutor. The role of the teachers in their schools is only as as the coach of cultural arts subjects, and they does not have a scientific background in dance, so that dance lessons are not taught at the school. On the other hand, a teacher must be required to be professional as a teacher. This means that teachers must be able and skilled both in terms of mastery of the material and in teaching it to students.

For this reason, it is necessary to find a solution by increasing the knowledge and skills and strategies of teachers in teaching dance in the schools they foster. One way that can be done is by conducting training in collaboration with the experts, in this case the UNP PKM TEAM from the same department, namely the Sendratasik Department, Dance Study Program. The teachers were given knowledge about the arts of dance and music, then dance skills training was carried out starting with making dance properties which were used as a source of inspiration to create simple dances with a double layered approach.

The step that must be taken is to form a collaboration between the PKM TEAM and partners in this case are teachers who act as classroom teachers. The PKM TEAM first looks for the root of the problems experienced by the teachers, and the next step the PKM TEAM finds a solution in the form of training and collaborating to make it easier to find solutions to the problems. In this case, the PKM TEAM conducts training on making dance properties as well as being a source of inspiration and generating dance creation ideas. The training in making dance properties is one of the implications of the subject matter of handicrafts and dance material which is summarized in the arts and culture subjects in the form of a theme. Related to the problems as stated above, the PKM TEAM provides training.

\section{METHOD}

The method used is a double layered method. This means that in the implementation of the training, handicrafts skills and dance skills are combined. The results of the handicrafts are used as a source of inspiration to give birth to motion through the process of exploration and imitation which will be arranged in a dance series. The technique used is to combine handicraft material with dance which is presented in a single theme.

\section{RESULTS AND DISCUSSION}

As a professional teacher, someone must be smart in analyzing the situation. This means that as a professional teacher there is no reason to say that he/she cannot do things related to his profession. For example, related to the teaching and learning process, even though teachers do not have a special scientific background in certain teaching materials, but as a classroom teacher at least they have the ability to choose strategies that are appropriate to the material to be taught in accordance with the learning objectives to be achieved.

In this case, the double layered method is one of the strategies that can be used to develop material in art and culture learning which is taught in one package or summarized in a theme unit that is collaborated between handicrafts, dance and music skills. Furthermore, the handicrafts are used for dance properties. Meanwhile, this property can also be used as inspiration for generating ideas. As stated by Smith [6] the creation of dance can be initiated through stimuli that can be used as inspiration to produce motion motifs.

What needs to be considered is that the training process must be accompanied by teacher guidance, as revealed by Hawkins [7] that through a careful training process the trainees/students who are guided will have full attention and deep inner awareness to be able to express what they are like. they feel and understand from the material that has been given. It is assumed that all classroom teachers can do this to overcome difficulties in developing material in the learning process of dance practice. For example, for handicraft materials, students are invited to make an ashtray from a shell, then to add an element, it seems to be colored according to the student's imagination.

Furthermore, the students are invited to explore the motion referring to the color characters that are affixed to the shell/ashtray, thus giving birth to various types of motion. Then the tempuruang as a dance property can be played/swiped or beaten to produce a sound which is used to regulate the rhythmic tempo and at the same time it can also be used as dance accompaniment music. The color affixed to the shell has a separate character meaning. Referring to the meaning/character of the color, the child is guided to explore the motion according to the meaning of the color used. Another example for the property is a fan made of origami paper, cardboard. Students are distributed colored origami paper and or white cardboard, but wait for students to color the cardboard 
according to their taste. Origami paper and or cardboard are processed by folding them to make a fan.

Then the red fan, for example, is used as a source of inspiration to explore bold, firm character motion, while the blue fan is used as a source of inspiration to give birth to soft motion. For the next step, the teachers collaborate with students to choose, select the motion motifs that have been obtained through the exploration process.

The next step, students under the guidance of the teacher assemble the motives of the movement, so that a series of dance movements is formed which is arranged in a dance sequence according to the theme raised in the dance. In this way students do not feel burdened, meaning that they can do it with fun and give birth to creative expressive movements which are the result of the search for the students themselves $[8,9,10$, 11]. Likewise, teachers can carry out the dance learning process without having to think about it first. , the form of movement that will be taught to students, but it is enough to develop an idea of the properties used in the dance to be achieved. The steps carried out can be seen in the following figure:

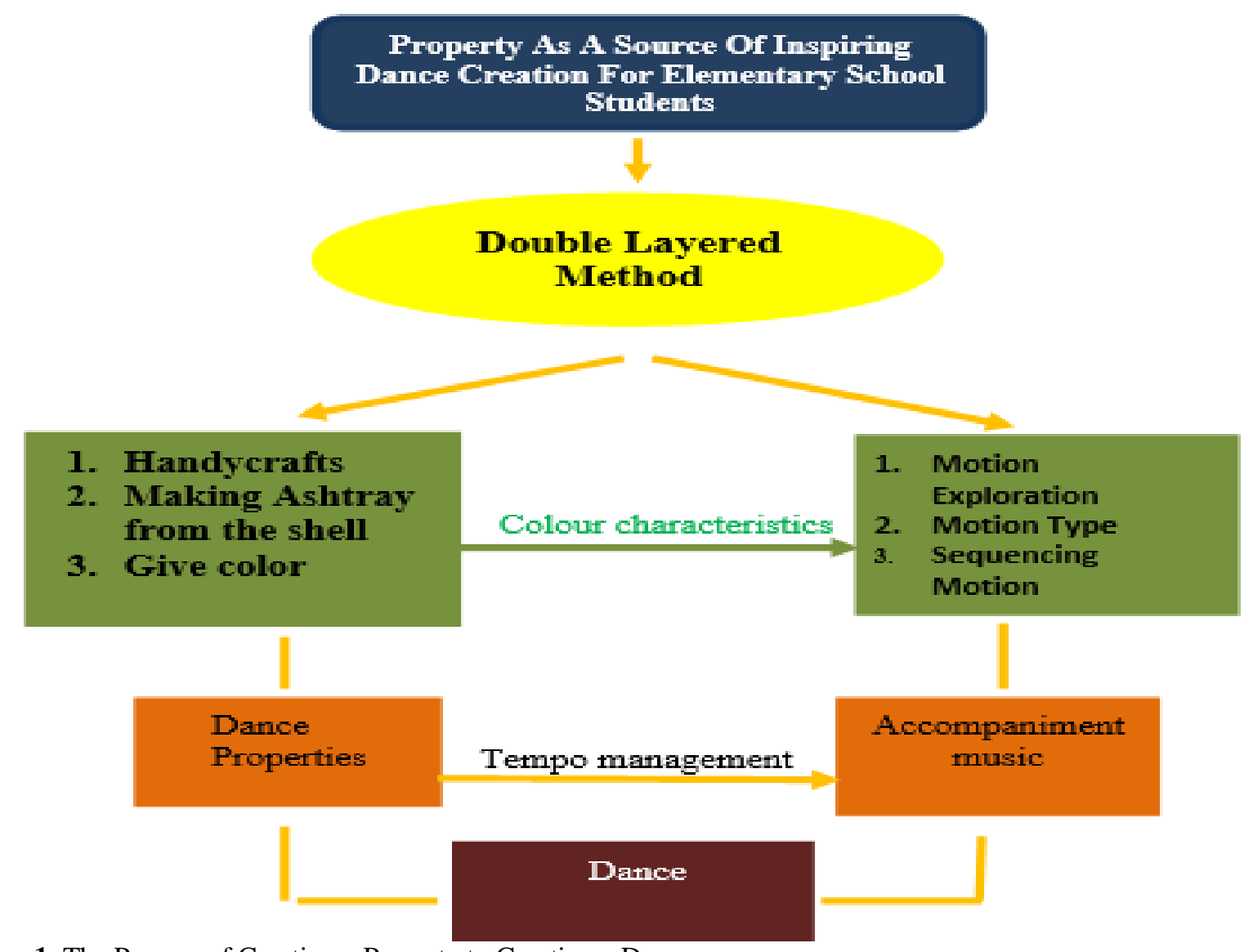

Figure 1. The Process of Creating a Property to Creating a Dance

The double layered method intended in this paper is that teaching dance is given to arts and culture subjects which are summarized in one theme of cultural arts subjects. It means to teach dance. taught in one package with crafts and music on a unified theme taught in one face-to-face. The results of handicrafts can be used as a property in dance at the same time. For example, handicrafts in the form of figures from cardboard, origami, flower frames from shells, cans of used goods, kites, from bamboo sharpeners, broom sticks from coconut leaves, and so on. All these handicrafts can be used as dance properties that are tailored to the dance theme and the dance learning objectives to be achieved. Thus this method is very easy to do and really helps teachers in teaching cultural arts, especially dance to be applied in schools $[12,13,14$, $15]$. 


\section{CONCLUSION}

The use of the multiple layered method by combining several materials that are cognate in one unified theme is very effective and efficient in teaching cultural arts, especially dance at school. This is very suitable with the K-13 curriculum which uses the concept of learning in one unified theme. Not only that, this method is also very meaningful for teachers who are not based on the field of art, but they must teach it in schools, especially for classroom teachers as it is applied at the elementary school level. Based on the results of the training that has been given, the teachers feel very motivated and helped in the dance learning process. They do not feel giddy and confused anymore to teach dance at school, even though they are only class teachers.

The success of the use of this multi-layered method can be seen in the trusting attitude of the teachers to practice it during the training process. Likewise, the students seemed focused, full of enthusiasm in following the learning process given by the instructors. In turn, the dance learning process which was previously considered unattractive learning, however, after being briefed, both theoretically and practically, the students carried out these activities in a fun and effortless manner. This means that the use of the double layered method is suitable for use in nonvocational schools, especially at the elementary school level, which is guided by class teachers.

\section{REFRENCES}

[1] Intasoni, S., Junpeng, P., Tang, K. N., Ketchatturat, J., Zhang, Y., \& Wilson, M. Developing an assessment framework of multidimensional scientific competencies. International Journal of Evaluation and Research in Education (IJERE), 9 (4), 963-970. 2020. 10.11591/ijere.v9i4.20542

[2] Ambarwangi, S. Pendidikan Multikultural di Sekolah melalui Pendidikan Seni Tradisi. Harmonia. $\quad 13(1), \quad 78-85 . \quad 2013$ https://media.neliti.com/media/publications/55854ID-pendidikan-multikultural-di-sekolah-mela.pdf

[3] Astuti, F. Menggali dan Mengembangkan potensi kreativitas Seni pada Anak Usia Dini.komposisi: Jurnal Pendidikan Bahasa, sastra, dan seni, 14 (1). 2013. https://doi.org/10.24036/komposisi.v14il.3950

[4] Astuti, F. The Effectiveness of Exploring Local Wisdom from Youtube: An Investigation on the Indonesian Higher Education Students' Dance Performance across Gender. Cakrawala Pendidikan. 40(1), 230-241. 10.21831/cp.v40i1.32426

[5] Murgianto, Sal. 1983. Koreografi pengetahuan Dasar Komposisi Tari. Departemen Pendidikan Dan Kebudayaan
[6] Smith, Jacqueline. 1985. Komposisi Tari, Sebagai Petunjuk Praktis Bagi Guru. Terjemahan Ben Suharto. Yogyakarta : Ikalasti.

[7] Hawkins, Alma M. 2002. Bergerak Menurut Kata Hati. MSPI : Jakarta.

[8] Fuji Astuti, 2016 Pengetahuan dan Teknik Menata Tari Untuk Anak Usia Dini. Jakarta .Kencana.

[9] Maraz, A., Kiraly, O., Urban, R., Griffiths, M. D., \& Demetrovics, Z. Why Do You Dance? Development of the Dance Motivation Inventory (DMI). PLOS one, 1-11. 2015.

[10] George, N., D, R, B., George, M., Venkataramani, S., M., K., S., A, P. M., \& Roy, R. Dance, sports or academics: which monopolize students emotional quotient. International Journal of Research in Medical Sciences, 6(11), 3714-3720. 2018.

[11] Payne, H., \& Costas, B. Creative Dance as Experiential Learning in State Primary Education: The Potential Benefits for Children. Journal of Experiential Education. 44(3), 277 -292

[12] Rahmida Setiawati dkk, 2008, Seni Tari Untuk Sekolah Menengah Kejuruan: Jakarta. Depertemen Pendidikan Nasional.

[13] Mokhtar, M. Art and Craft in the Era of Creative Industry in Malaysia. ARS: Jurnal Seni Rupa dan Desain, 21(1), 134-143. 2018.

[14] Mahgoub. Y. M., \& Alsoud, K. F. The Impact of Handicrafts on the Promotion of Cultural and Economic Development for Students of Art Education in Higher Education. Journal of Literature and Art Studies. 5 (6), 471-479.

[15] Wang, Z. Analysis on Application of Traditional Arts and Crafts in Exhibition Design. Open Journal of Social Sciences, 5, 85-89. 2017. 